\title{
Avifauna of Lehua Islet, Hawai'i: Conservation Value and Management Needs ${ }^{1}$
}

\author{
Eric A. VanderWerf, $, 2,6$ Ken R. Wood, ${ }^{3}$ Chris Swenson, ${ }^{2}$ Maya LeGrande, ${ }^{4}$ Heather Eijzenga, ${ }^{5}$ and \\ Ronald L. Walker ${ }^{2}$
}

\begin{abstract}
We conducted surveys from 2002 to 2005 and compiled historical information on the avifauna of Lehua Islet, Hawai' $i$, to assess its conservation status and management needs. Thirty-five bird species have been observed on Lehua since 1931, including 18 seabirds endemic or indigenous to the Hawaiian Islands, one resident indigenous waterbird, six migratory waterbirds, and 10 alien land birds. We observed 29 of these species during surveys from 2002 to 2005,13 of which had not been recorded on the islet previously. Over 25,000 pairs of eight seabird species were documented to breed on Lehua, including previously unknown breeding colonies of Black-footed Albatross (Phoebastria nigripes) and Laysan Albatross (P. immutabilis), and the largest breeding colonies of Brown Booby (Sula leucogaster) and Red-footed Booby (S. sula) in the Hawaiian Islands. Remains of a Newell's Shearwater (Puffinus auricularis newelli) chick and a Band-rumped Storm-Petrel (Oceanodroma castro) chick were found, demonstrating that those species have nested on the islet and probably still do. The nesting season varied among species, with most species breeding from March to August, and at least one species breeding in every month. Predation by alien Polynesian rats (Rattus exulans) and Barn Owls (Tyto alba) is the most serious threat to nesting seabirds on Lehua. Sediment beneath a Barn Owl roost contained hundreds of bones from a variety of bird species, including Brown Noddy (Anous stolidus), which has been extirpated from the islet. Feral rabbits (Oryctolagus cuniculus) are suppressing vegetation that could provide additional nest sites for Red-footed Boobies and help prevent erosion and burying of seabird burrows. The most urgent management needs on Lehua are eradication of alien Polynesian rats, alien Barn Owls, and feral rabbits. Rocky offshore islets like Lehua may become increasingly important in seabird conservation because their small size makes it more feasible to manage threats, and because they are less likely to be affected by increases in sea level associated with climate change.
\end{abstract}

\footnotetext{
${ }^{1}$ Funding for this project was provided by the U.S. Fish and Wildlife Service and Pelea pacifica. Manuscript accepted 24 February 2006.

${ }^{2}$ Pacific Rim Conservation, 320 Kupaua Place, Honolulu, HI 96821.

${ }^{3}$ Pelea pacifica, P.O. Box 745, 'Ele'ele, Kaua'i, Hawai'i 96705.

${ }^{4}$ Bernice P. Bishop Museum, 1525 Bernice Street, Honolulu, Hawai'i 96817.

${ }^{5}$ Department of Botany, St. John Hall, University of Hawai'i at Mānoa, Honolulu, Hawai'i 96822.

${ }^{6}$ Corresponding author (eric@pacificrimconservation .org).
}

Pacific Science (2007), vol. 61, no. 1:39-52

(C) 2007 by University of Hawai'i Press

All rights reserved
Lehua Islet is a small, crescent-shaped volcanic islet located $1.2 \mathrm{~km}$ north of $\mathrm{Ni}^{6}$ ihau and $31 \mathrm{~km}$ west of Kaua'i, Hawai'i (Figure 1). The avifauna of Lehua Islet has been surveyed only six times, beginning in 1931 (Caum 1936), and was last surveyed in 1967 (R.L.W., unpubl. data). Because of its isolation, Lehua has been an important breeding site for seabirds (Harrison 1990), but the current status and conservation needs of seabird species nesting on Lehua are poorly known. Polynesian rats (Rattus exulans) and feral rabbits (Oryctolagus cuniculus) have been present on Lehua since at least the 1930s (Caum 1936), and they may be impacting seabird 


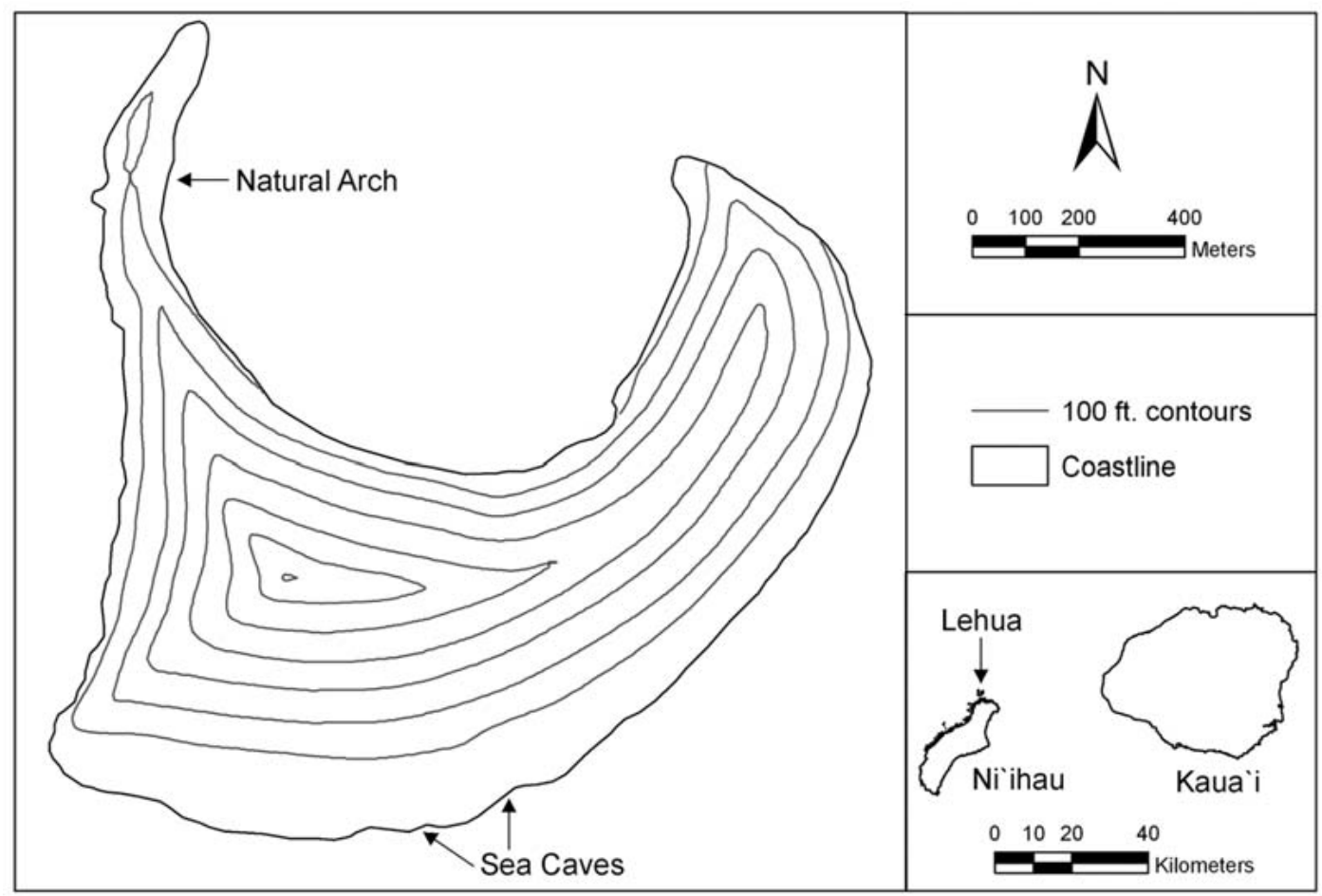

FIgURE 1. Map of Lehua Islet, showing locations of sea caves used for nesting by Black Noddies and a natural arch that may be a partial barrier to feral rabbits and rats.

populations. Lehua is considered a priority site for conservation work by the Offshore Islet Restoration Committee, a group dedicated to the preservation and restoration of offshore islets in the Hawaiian Islands. As part of a biological inventory and conservation assessment of Lehua Islet, we conducted surveys of the avifauna from 19 to 21 February 2002, 6-8 July 2002, 30 May-2 June 2003, and 13-17 July 2004. Additional observations on some species were made during visits from 20 to 21 December 2001, 7-9 March 2003, 28 September 2003, 10-11 April 2005, and 5-7 October 2005. Here we summarize the current status of the avifauna, compile historical information to examine temporal changes, assess threats, and recommend management actions to enhance the value of the island for native bird species. The results of botanical surveys are presented elsewhere (Wood and LeGrande 2006).
MATERIALS AND METHODS

\section{Study Site}

The tuff crater that now forms Lehua Islet was created 4.89 million yr ago during a secondary volcanic event $14.5 \mathrm{~km}$ northnorthwest of the summit crater of $\mathrm{Ni}^{\text {icihau }}$ (Carson and Clague 1995). The crater is now highly eroded and nearly half submerged, forming a steep, crescent-shaped island with an area of $1.1 \mathrm{~km}^{2}$, a length of $2 \mathrm{~km}$, and a maximum elevation of $213 \mathrm{~m}$ (Figure 1). The upper slopes of the inner crescent are composed of parallel tuff strata that have eroded at different rates, producing a series of weathered ledges 1-2 m wide and 1-2 m high, like a series of steps forming a large amphitheater. These ledges are most developed on the western point, where differential weathering has produced thousands of overhung ledges and shallow caves $25-100 \mathrm{~cm}$ deep, many of 
which are used for nesting by seabirds. The lower slope of the inner crescent has several deeply eroded fissures and chasms. The outer crescent is smoother than the inner crescent, but has several eroded gullies that widen near the shore. Cliffs up to $55 \mathrm{~m}$ in height occur on the eastern and western points of the island. The U.S. Coast Guard maintains a small solar-powered light at the summit of Lehua to guide navigators.

Two sea caves are present on the outer crescent (Figure 1), which are used for nesting by Hawaiian Black Noddies (Anous minutus melanogenys). Approximately $350 \mathrm{~m}$ before the western point is a natural arch that allows the ocean to pass between the inner and outer crescents. The top of this natural arch is very narrow and may inhibit rats and rabbits from reaching the western tip of the islet. The arch is currently solid enough to support human foot traffic, but a fault line is present in the remaining block of tuff that forms the arch; when this fault fails the western point will be isolated from the rest of the islet.

A broad, shallow cave formed by an overhanging cliff is present toward the western end of the outer crescent. A ledge on the cliff is used as a roost by Barn Owls (Tyto alba), and owl pellets have accumulated in the fine sediment on the cave floor under the roost. Thousands of bird and mammal bones have accumulated in the sediment, indicating that it has been used as a roost by Barn Owls for many years. These prey remains provide a valuable record of the animal species present on Lehua in the recent past. We excavated a portion of this deposit in July 2004 and identified some of the bones by comparison with reference specimens at the Bernice P. Bishop Museum, but the majority of bones have not been identified yet and results of that work will be presented elsewhere (D. Burney and E.A.V., unpubl. data).

\section{Avifauna Surveys}

We surveyed all parts of the island that were accessible on foot and noted the number of individuals of each bird species, the number and status of nests, and any reproductive behavior. Special effort was made to search for nesting birds and signs of predators in caves, crevices, and underneath ledges. A few areas were surveyed from a distance due to very steep terrain, including the cliffs on the western face and the deep chasms on the lower slopes of the inner crescent. To reduce the chance of counting birds twice, we only counted birds on the ground, not flying birds. Numbers of nests included unattended eggs in nests that appeared to be active and adults that appeared to be incubating or brooding. Birds were not disturbed to ascertain nest contents.

For larger species that nested on the surface and were readily visible from a distance, these data comprise a complete census of the breeding population, though the numbers reported may be slight underestimates because a few birds may have been missed. For species that nested underground, we opportunistically sampled portions of the islet that were safely accessible on foot and extrapolated to obtain a population estimate for the whole islet. For rare species and migrants that were not expected to occur in all parts of the island, the values presented are the actual counts. Nonbreeding individuals of several species were present but were more difficult to survey, and in most cases the numbers reported apply to the breeding population.

To examine temporal changes in the avifauna of Lehua Islet, we compiled information from previous ornithological surveys, including those from 18 to 22 April 1931 and 17-18 August 1932 (Caum 1936), 12-16 August 1947 (Fisher 1951), 10-11 August 1960 (Richardson 1963), and 8 September 1966 and 10 September 1967 (R.L.W., Hawai'i Division of Forestry and Wildlife, unpubl. data).

\section{RESULTS}

Thirty-five bird species have been observed on Lehua Islet or in waters immediately adjacent during all visits since 1931, including 18 seabird species endemic or indigenous to the Hawaiian Islands, one resident indigenous waterbird species, six species of migratory waterbirds that visit Hawai' $i$ in the winter during their nonbreeding season, and 10 resident alien land bird species (Table 1). 
TABLE 1

Summary of Historical and Recent Bird Surveys on Lehua Islet

\begin{tabular}{|c|c|c|c|c|c|c|c|c|c|c|}
\hline \multirow[b]{2}{*}{ Species } & \multirow[b]{2}{*}{ Status $^{a}$} & \multirow[b]{2}{*}{$\begin{array}{c}1931,1932 \\
(\text { Caum 1936) }\end{array}$} & \multirow[b]{2}{*}{$\begin{array}{l}1947 \\
\text { (Fisher } \\
1951 \text { ) }\end{array}$} & \multirow[b]{2}{*}{$\begin{array}{c}1960 \\
\text { (Richardson } \\
1963 \text { ) }\end{array}$} & \multirow{2}{*}{$\begin{array}{c}1966, \\
1967 \\
\text { (R.L.W., } \\
\text { unpubl. } \\
\text { data) }\end{array}$} & \multicolumn{5}{|c|}{ 2002-2004 (this study) } \\
\hline & & & & & & $\begin{array}{l}\text { Survey } \\
\text { type }^{b}\end{array}$ & $\begin{array}{l}19-21 \\
\text { Feb. } \\
2002\end{array}$ & $\begin{array}{c}6-8 \\
\text { July } \\
2002\end{array}$ & $\begin{array}{c}30 \\
\text { May-2 } \\
\text { June } 2003\end{array}$ & $\begin{array}{c}13-17 \\
\text { July } \\
2004\end{array}$ \\
\hline \multirow{2}{*}{$\begin{array}{l}\text { Black-footed Albatross } \\
\text { (Phoebastria nigripes) }\end{array}$} & \multirow[t]{2}{*}{ Ind SoC } & \multirow{2}{*}{$\begin{array}{l}\text { A few, no } \\
\text { nests }\end{array}$} & \multirow[t]{2}{*}{0} & \multirow[t]{2}{*}{0} & \multirow[t]{2}{*}{0} & Adults C & 31 & 0 & 2 & 0 \\
\hline & & & & & & Chicks C & 8 & 0 & 11 & 0 \\
\hline \multirow{2}{*}{$\begin{array}{l}\text { Laysan Albatross (Phoebastria } \\
\text { immutabilis) }\end{array}$} & \multirow{2}{*}{ Ind SoC } & \multirow[t]{2}{*}{0} & \multirow[t]{2}{*}{0} & \multirow[t]{2}{*}{0} & \multirow[t]{2}{*}{0} & Adults C & 50 & 0 & 10 & 0 \\
\hline & & & & & & Chicks C & 9 & 4 & 28 & 2 \\
\hline $\begin{array}{l}\text { Hawaiian Petrel (Pterodroma } \\
\text { sandwichensis) }\end{array}$ & End $\mathrm{E}$ & 0 & 0 & 0 & 0 & Adults C & 0 & 0 & 0 & 1 \\
\hline $\begin{array}{l}\text { Wedge-tailed Shearwater } \\
\text { (Puffinus pacificus) }\end{array}$ & Ind & $\begin{array}{l}\text { Very } \\
\text { common }\end{array}$ & $1,000 \mathrm{~s}$ & 1,500 nests & $\begin{array}{l}1,000-1,200 \\
\text { nests }\end{array}$ & Nests S & 0 & 23,000 & 100 & * \\
\hline $\begin{array}{l}\text { Christmas Shearwater (Puffinus } \\
\text { nativitatus) }\end{array}$ & Ind SoC & 0 & * & 0 & 0 & Adults A & 0 & 2 & 1 & 1 \\
\hline \multirow{2}{*}{$\begin{array}{l}\text { Newell's Shearwater (Puffinus } \\
\text { auricularis newelli) }\end{array}$} & \multirow[t]{2}{*}{ End $T$} & \multirow[t]{2}{*}{0} & \multirow[t]{2}{*}{0} & \multirow[t]{2}{*}{0} & \multirow[t]{2}{*}{0} & Adults A & 0 & 0 & 1 & 24 \\
\hline & & & & & & Skeletons A & 1 & 0 & 0 & 0 \\
\hline \multirow{3}{*}{$\begin{array}{l}\text { Bulwer's Petrel (Bulweria } \\
\text { bulwerii) }\end{array}$} & \multirow[t]{3}{*}{ Ind } & \multirow[t]{3}{*}{0} & \multirow[t]{3}{*}{0} & 40 & \multirow[t]{3}{*}{0} & Adults A & 0 & 6 & 60 & 62 \\
\hline & & & & 4 & & Nests A & 0 & 6 & 9 & 6 \\
\hline & & & & 8 & & Carcasses A & 0 & 3 & 0 & 4 \\
\hline \multirow{2}{*}{$\begin{array}{l}\text { Band-rumped Storm-Petrel } \\
\text { (Oceanodroma castro) }\end{array}$} & Ind $\mathrm{C}$ & 0 & 0 & 0 & 0 & Adults A & 0 & 1 & 6 & 1 \\
\hline & & & & & & Skeletons A & 1 & 0 & 0 & 0 \\
\hline Red-tailed Tropicbird (Phaethon & Ind & & 400 adults & 250 adults & $30-40$ nests & Adults A & 76 & 150 & * & * \\
\hline rubricauda) & & $\begin{array}{l}\text { Most } \\
\text { common } \\
\text { species }\end{array}$ & & & & Nests S & 2 & 200 & * & * \\
\hline $\begin{array}{l}\text { White-tailed Tropicbird } \\
\text { (Phaethon lepturus) }\end{array}$ & Ind & 0 & 2 adults & 0 & 0 & Adults A & 0 & 0 & 0 & 1 \\
\hline Masked Booby (Sula dactylatra) & Ind & $\begin{array}{l}\text { A few, 2-3 } \\
\text { nesting } \\
\text { pairs }\end{array}$ & 0 & 0 & 0 & Adults C & 0 & 0 & 0 & 0 \\
\hline Brown Booby (Sula leucogaster) & Ind & A few nesting & 0 & 120 adults & 170 young & Adults C & 303 & * & * & * \\
\hline & & pairs & & & & Nests C & 12 & 369 & 521 & * \\
\hline Red-footed Booby (Sula sula) & Ind & Not & 3,000 adults & 500 adults & $1,500-1,800$ & Adults C & 4,288 & * & * & * \\
\hline & & uncommon & & & nests & Nests C & 0 & 1,294 & * & * \\
\hline Great Frigatebird (Fregata minor) & Ind & Rare, 2-3 & & 18 & $25-30$ adults & Adults C & 38 & 326 & 77 & * \\
\hline & & $\begin{array}{l}\text { nesting } \\
\text { pairs }\end{array}$ & & 0 & & Nests C & 0 & 0 & 0 & 0 \\
\hline
\end{tabular}




\begin{tabular}{|c|c|c|c|c|c|c|c|c|c|c|}
\hline \multirow[t]{2}{*}{ Cattle Egret (Bubulcus ibis) } & \multirow[t]{2}{*}{$\mathrm{A}$} & \multirow[t]{2}{*}{0} & \multirow[t]{2}{*}{0} & \multirow[t]{2}{*}{0} & \multirow[t]{2}{*}{0} & \multirow{2}{*}{$\begin{array}{l}\text { Adults C } \\
\text { Nests C }\end{array}$} & \multirow{2}{*}{$\begin{array}{r}19 \\
0\end{array}$} & \multirow{2}{*}{$\begin{array}{l}9 \\
2\end{array}$} & \multirow{2}{*}{$\begin{array}{l}87 \\
21\end{array}$} & \multirow{2}{*}{$\begin{array}{l}1 \\
2\end{array}$} \\
\hline & & & & & & & & & & \\
\hline $\begin{array}{l}\text { Black-crowned Night-Heron } \\
\text { (Nycticorax nycticorax) }\end{array}$ & Ind & 0 & 0 & 0 & 0 & Adults & 0 & 0 & 0 & 1 \\
\hline $\begin{array}{l}\text { Peregrine Falcon (Falco } \\
\text { peregrinus) }\end{array}$ & WV SoC & 0 & 0 & 0 & 0 & Adults A & 1 & 0 & 0 & 0 \\
\hline $\begin{array}{l}\text { Pacific Golden-Plover (Pluvialis } \\
\text { fulva) }\end{array}$ & WV SoC & Several & 0 & 0 & 3,3 & Adults A & 6 & 0 & 0 & 0 \\
\hline $\begin{array}{l}\text { Wandering Tattler (Heteroscelus } \\
\text { incanus) }\end{array}$ & WV & 0 & 0 & 2 & 1 & Adults A & 0 & 1 & 0 & 1 \\
\hline $\begin{array}{l}\text { Ruddy Turnstone (Arenaria } \\
\text { interpres) }\end{array}$ & WV & Several & 0 & 20 & 3,6 & Adults A & 9 & 8 & 0 & 6 \\
\hline $\begin{array}{l}\text { Glaucous-winged Gull (Larus } \\
\text { glaucescens) }\end{array}$ & WV & 0 & 0 & 0 & 0 & Adults A & 1 & 0 & 0 & 0 \\
\hline $\begin{array}{l}\text { Gray-backed Tern (Sterna } \\
\text { lunata) }\end{array}$ & Ind & 0 & 0 & 0 & 0 & Adults A & 0 & 1 & 0 & 0 \\
\hline Sooty Tern (Sterna fuscata) & Ind & 0 & 0 & 0 & 0 & Adults A & 2 & 0 & 2 & 1 \\
\hline Brown Noddy (Anous stolidus) & Ind & $\begin{array}{l}\text { Fairly } \\
\text { common }\end{array}$ & 0 & 0 & 500 adults & Adults A & 1 & 0 & 0 & 0 \\
\hline $\begin{array}{l}\text { Hawaiian Black Noddy (Anous } \\
\text { minutus melanogenys) }\end{array}$ & End & Rare & 200 & 350 & $\begin{array}{r}335-360 \\
\text { adults }\end{array}$ & Adults C & 136 & 405 & 230 & * \\
\hline Rock Dove (Columba livia) & A & 0 & 0 & 0 & 0 & Adults A & 0 & 0 & 2 & 0 \\
\hline Zebra Dove (Geopelia striata) & $\mathrm{A}$ & 0 & A few & 6 & 2,7 & Adults A & 0 & 0 & 0 & 0 \\
\hline Sky Lark (Alauda arvensis) & $\mathrm{A}$ & $\begin{array}{l}\text { Rather } \\
\text { common }\end{array}$ & $*$ & 0 & 0 & Adults A & 0 & 0 & 0 & 0 \\
\hline $\begin{array}{l}\text { Northern Cardinal (Cardinalis } \\
\text { cardinalis) }\end{array}$ & A & 0 & 0 & 1 & 0 & Adults A & 0 & 0 & 0 & 0 \\
\hline $\begin{array}{l}\text { House Finch (Carpodacus } \\
\text { mexicanus) }\end{array}$ & A & 0 & 0 & 20 & $18,40-45$ & Adults A & 0 & 2 & 0 & 4 \\
\hline $\begin{array}{l}\text { Nutmeg Mannikin (Lonchura } \\
\text { punctulata) }\end{array}$ & $\mathrm{A}$ & 0 & 0 & 0 & 1,16 & Adults A & 0 & 20 & 15 & 34 \\
\hline $\begin{array}{l}\text { House Sparrow (Passer } \\
\text { domesticus) }\end{array}$ & A & 0 & 0 & 10 & 12,0 & Adults A & 0 & 0 & 0 & 0 \\
\hline
\end{tabular}

a Status codes: End, endemic to the Hawaiian Islands; Ind, indigenous to the Hawaiian Islands; WV, indigenous winter visitor; A, alien; E, endangered; T, threatened; C, candidate; SoC, species of

${ }^{b}$ Survey type codes: C, census; S, sample; A, actual count. See Materials and Methods for description of each survey type.

* Indicates that the species was observed but its abundance was not estimated. 


\begin{tabular}{|l|l|l|l|l|l|l|l|l|l|l|}
\hline Black-footed Albatross & & & & & & & \\
\hline
\end{tabular}

Figure 2. Breeding phenology of seabirds on Lehua Islet. Extent of each stage of the breeding cycle was extrapolated from dates of visits and incubation and fledging periods in other locations. Additional species known or suspected to nest on Lehua but for which there is insufficient information to determine breeding phenology include Christmas Shearwater, Newell's Shearwater, and Band-rumped Storm-Petrel. --- = eggs; $-=$ chicks.

We observed 29 of these species during surveys from 2002 to 2005,13 of which had not been recorded on the islet previously. These included one endangered species, one threatened species, one species that is a candidate for listing, and five species of conservation concern (Table 1). Wedge-tailed Shearwater (Puffinus pacificus) was by far the most numerous species, followed by Red-footed Booby (Sula sula), and Brown Booby (Sula leucogaster). Several species were represented by only one or a few individuals and may occur on the island irregularly. More detailed information about species of particular interest is provided in the following species accounts.

Over 25,000 pairs of eight seabird species currently nest on Lehua Islet (Table 1), and two additional species have nested on the islet in the past and probably still do, based on remains of juveniles that were too small to fly. Two more species are suspected of breeding, although no nests or remains were found. The nesting season varied among species, with the largest number of species breeding from March to August and at least one species breeding in every month (Figure 2).

On 31 May 2003 and 15 July 2004 many seabirds were observed at dusk flying past the western point and forming a large flock that circled about $500 \mathrm{~m}$ offshore. The flock consisted primarily of Wedge-tailed Shear- waters, with smaller numbers of Bulwer's Petrels (Bulweria bulwerii), Newell's Shearwaters (Puffinus auricularis newelli), Christmas Shearwaters (Puffinus nativitatus), and at least one Hawaiian Petrel (Pterodroma sandwichensis). Some of these birds began flying toward Lehua as it became dark and may have been headed toward nests on the islet. Radar monitoring of similar flocks off Kaua'i has shown that such birds fly to inland breeding sites primarily after dark (Day et al. 2003).

We observed three alien predators of birds on Lehua, the Polynesian rat, Barn Owl, and Cattle Egret (Bubulcus ibis), and we found evidence that a least two of these species, the Barn Owl and Polynesian rat, were preying on seabirds. Several Barn Owl pellets were collected from a long-term roost site, and thousands of bones from a variety of bird species were found in sediment under the roost. The carcasses of several Bulwer's Petrels were found with evidence of predation by rats and by Barn Owls. We found several Wedge-tailed Shearwater eggs with rat tooth marks, including one egg that had rat tracks from ink on a nearby tracking board (R. Doratt and L. Driscoll, U.S. Department of Agriculture-Animal and Plant Health Inspection Service). Cattle Egrets are known to prey on seabird nestlings in other areas (Telfair 1994) and may be competing for nesting space with Red-footed Boobies. 
Species Accounts

BLACK-FOOTED ALBATROSS (Phoebastria nigripes): Caum (1936) reported seeing a few individuals of this species on Lehua, none of which was nesting. Harrison (1990) reported that breeding was suspected on Lehua but that no nests or chicks had been found. In February 2002, we observed 10 adults tending eight small chicks, and 21 nonbreeding adults. In July 2002, no adults, chicks, or carcasses were present, suggesting that all eight chicks had fledged. In May 2003, we observed 11 large, healthy chicks. On 10 April 2005, we observed 16 large chicks, indicating that the number of breeding pairs may be increasing. All nests were on the western end of the inner slope $20-100 \mathrm{~m}$ below the summit.

It is difficult to determine when albatrosses began breeding on Lehua because most previous surveys occurred in months outside the albatross breeding season. The only previous survey that occurred when albatrosses would have been nesting was in March 1931 by Caum, who reported only a few nonbreeding adults. The Black-footed Albatross is regarded as a species of conservation concern by the U.S. Fish and Wildlife Service (2002a) and as endangered by the International Union for the Conservation of Nature (2003), due to its restricted breeding distribution and relatively small global population size of approximately 58,000 breeding pairs, most of which breed in the Northwestern Hawaiian Islands (Whittow 1993a, U.S. Fish and Wildlife Service 2005), so the presence of an additional breeding colony on Lehua is important. The only other colony in the main Hawaiian Islands is on Ka'ula, where estimates of the number of breeding pairs range from 20 to 70 (Harrison 1990) to 100 (Fefer et al. 1987).

LAYSAN ALBATROSS OR MŌLĪ (Phoebastria immutabilis): This species has not been reported previously on Lehua. In February 2002, we observed 13 adults tending nine small chicks, and 37 nonbreeding adults. In July 2002, four large, healthy chicks appeared ready to fledge and no carcasses were found, suggesting that the other five chicks had fledged. In May 2003, we observed 27 large, healthy chicks and one dead chick. The dead chick showed no internal or external signs of injury or predation but did have several small pieces of plastic in its crop. On 10 April 2005, we observed 15 large chicks. Nests were concentrated on the western end of the inner slope 20-100 $\mathrm{m}$ below the summit, and in 2003 one nest was located on the western end of the outer slope.

The Laysan Albatross went through a severe population decline and was extirpated from several breeding islands in the early 1900s due to feather collecting (Whittow $1993 b$ ), but small population increases have occurred at Kīlauea Point, Kaua'i, and Ka'ena Point, O‘ahu, in the last 20 yr (Harrison 1990, Sugimura et al. 2003; L. Young, unpubl. data), and new breeding colonies have been established recently in the Ogasawara Islands near Japan (Hasegawa 1978) and on islands off the west coast of Mexico, including Guadelupe Island, San Benedicto Island, Isla Clarion, and Alijos Rocks (Pitman 1985, 1988, Dunlap 1988, Howell and Webb 1989, 1992). Although the global number of Laysan Albatross is relatively large, approximately 630,000 breeding pairs (U.S. Fish and Wildlife Service 2005), colonies on high islands such as Lehua may become increasingly valuable because they are less likely to be affected by increases in sea level associated with climate change.

WEDGE-TAILED SHEARWATER OR 'UA'U KANI (Puffinus pacificus): This species was reported to be very common on all previous surveys, but the number of breeding pairs estimated in this study is much higher than any previous estimate (Table 1). In July 2002 we counted a total of 2,300 nests in areas comprising approximately $10 \%$ of the islet, yielding a population estimate of approximately 23,000 pairs, making Lehua the fifth largest breeding site for this species in the Hawaiian Islands, after Laysan, Nīhoa, Mānana, and Lisianski (Fefer et al. 1987). Nests were distributed throughout the islet in a variety of caves, crevices, and burrows, under overhanging ledges, under vegetation, and even on the surface in the open. We observed several unusual nests in which dense grass had been pushed up to create a domed shelter over the egg. This species typically returns to breeding 
areas in March-April to select nest sites and mate, then exhibits an exodus of roughly one month, returning to lay eggs in June (Whittow 1997).

CHRISTMAS SHEarwater (Puffinus nativitatus): This species is common in the Northwestern Hawaiian Islands and was reported on Lehua by Fisher (1951). We observed one or two birds flying over the islet or just offshore on 6 July 2002, 1 June 2003, and 15 July 2004. We did not find any nests, but it seems likely that they were nesting.

NEWELL's SHEARWATER OR 'A'O (Puffinus auricularis newelli): This subspecies is endemic to the main Hawaiian Islands and is listed as threatened under the U.S. Endangered Species Act. It has not been reported from Lehua previously. On 30 May 2003, we heard one bird calling from the islet, and in February 2002 we collected the desiccated remains of a partially developed Newell's Shearwater chick from a small cave. On 15 July 2004, we observed 24 birds flying past the western tip from 1855 to 1930 hours. These birds joined a large flock of Wedgetailed Shearwaters and other birds that circled offshore, and they may have flown to nest sites on the islet after dark. Newell's Shearwaters are thought to nest primarily under thick vegetation on mountain slopes (Ainley et al. 1997), but substantial numbers also occur on sparsely vegetated cliffs in remote valleys on the dry leeward side of Kaua'i (Wood et al. 2002), so their occurrence in similar rocky habitat on Lehua is not surprising. Eradication of alien predators and rabbits would enhance nesting habitat for this species on Lehua.

HaWAilan PeTRel OR 'UA'U (Pterodroma sandwichensis): This endangered species has not been recorded previously from Lehua. On 15 July 2004, we observed a single bird fly past the western tip of the islet and join a large flock that circled offshore. As with Newell's Shearwater, this bird may have returned to a nest on Lehua after dark, or it may have paused near Lehua while returning to a nesting area on Kaua'i. On Haleakalā, Maui, and Mauna Loa, Hawai'i, Hawaiian Petrels nest in rocky habitat similar to that on Lehua (Simons and Hodges 1998, Hu et al. 2001). Introduced predators are the most serious threat to this species (Hodges and Nagata 2001).

BULWER's PETREL OR 'OU (Bulweria bulwerii): This species was observed previously on Lehua only by Richardson (1963). We found several active nests on visits from May to July (Table 1). All nests were located in small rock crevices that likely were inaccessible to Wedge-tailed Shearwaters. We located most nests first by the soft barking calls of an adult. The breeding population of this species on Lehua probably is much larger than the number of nests counted because suitable nest sites are abundant, but the secretive habits of this species and windy conditions made it difficult to hear adults and find nests. We observed 60 or more birds flying past the western tip of the islet at dusk on 1 June 2003 and 15 July 2004, and it seems likely that these birds were returning to nests on the islet.

Bulwer's Petrels may be particularly vulnerable to predation due to their small size, and predation by Barn Owls and rats appears to be seriously affecting Bulwer's Petrels on Lehua. Richardson (1963) found the carcasses of eight adults that appeared to have been depredated, and we found eight more carcasses in 2002-2005. In each case the flesh on the breast and neck had been eaten and in some cases the head and wings were missing. We also found numerous Bulwer's Petrel bones in sediment under the Barn Owl roost. Bulwer's Petrels have disappeared from many islands where rats have been introduced but are beginning to recover on some islands where rats have been eradicated, such as Midway (Megyesi and O'Daniel 1997) and Kure (D. Smith, pers. comm.).

BAND-RUMPED STORM-PETREL OR

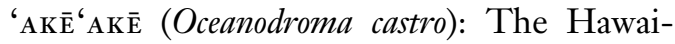
ian population of this species is a candidate for listing under the U.S. Endangered Species Act (U.S. Fish and Wildlife Service 2002b). It has not been reported previously from Lehua, but several specimens were collected from Ni'ihau in the late 1800s (Slotterback 2002). We heard Band-rumped Storm-Petrel calls 
on Lehua on 6 July 2002 and 1 June 2003. We also observed six birds circling just off the western tip of the islet at dusk on 1 June 2003, and one more on 15 July 2004. In February 2002, we collected the skull of a juvenile storm-petrel from a small cave. Although the specimen has not been identified conclusively, it is most likely to be a Bandrumped Storm-Petrel because they have been observed on the island. Another possibility is Tristram's or Sooty Storm-Petrel (O. tristrami), which is an abundant breeder on $\mathrm{N}^{-}-$ hoa and should be looked for on Lehua during the winter months. Although no active Band-rumped Storm-Petrel nests have been found on Lehua, it is very likely that they continue to nest on the islet in small numbers. Nests of this species are notoriously difficult to find, and no active nests have been located anywhere in the Hawaiian Islands, even though they are known to occur on at least two islands (Slotterback 2002). The small size of storm-petrels makes them particularly vulnerable to predation.

RED-TAILED TROPICBIRD OR KOA'E 'Ula (Phaethon rubricauda): This species was sparsely distributed over much of the islet but was difficult to survey because many nests were located in caves and under ledges on steep slopes and cliffs that were difficult to access. In July 2002 we counted 150 adults and 40 nests in areas comprising roughly $20 \%$ of the suitable habitat on the island, resulting in an extrapolated breeding population estimate of 200 pairs, which is similar to previous estimates (Table 1). In February 2002 only two nests were found, each with an egg, indicating the breeding season had just started. In MayJune 2003 most nests contained small to medium-sized chicks. In July 2002 and 2004 most nests contained large, feathered chicks. On 28 September 2003 one nest was found, containing a large chick.

BROWN воOBY OR 'A A (Sula leucogaster): On 30-31 May 2003 we counted 521 active nests, making Lehua the largest Brown Booby breeding colony in the Hawaiian Islands (Harrison 1990). In addition, groups of up to 47 nonbreeding birds were observed resting on cliffs in several areas. The numbers of adults and nests counted in this study are much higher than previous estimates (Table 1), indicating either that the population has increased or that previous estimates were low, perhaps because surveys were conducted outside the main breeding season.

This species had a protracted breeding season from mid-February through at least October (Figure 2). On 19 February 2002, only 12 active nests were found, but approximately 20 more nests contained fresh green vegetation, including facquemontia oliviformis, Pluchea indica, and Panicum torridum. On 31 May 2003, nests contained eggs (20\%), small naked chicks (50\%), and medium-sized downy chicks (30\%). In July 2002 and July 2004 , nests contained eggs (5\%), small naked chicks (5\%), medium-sized downy chicks $(30 \%)$, large feathered chicks $(30 \%)$, and fledged juveniles (30\%). In October 2005 a few nests still contained small chicks.

RED-FOOTED ВоОвY OR 'Ā (Sula sula): In July 2002 we counted 1,294 active nests, which is similar to previous estimates by Fisher (1951) and R.L.W. (unpubl. data) but probably is a slight underestimate because nests were difficult to see in some areas. In February 2002 we counted 2,352 adults and subadults, but surveys were done in late morning and afternoon when many birds were at sea foraging. We calculated a temporal correction for this by comparing the numbers of birds in two gulches at dawn before birds left and during the middle of the day. Repeated midday counts in those gulches yielded averages of 170.5 and 61.3 birds, and counts at dawn revealed 318 and 109 birds, respectively. Based on the resulting average correction of 1.82 , the number of birds that would have been present at dawn in all parts of the islet was 4,288 .

Red-footed Boobies had a protracted breeding season from late February through October. In February 2002 no active nests were present, but many birds were gathering nest material and several nests contained fresh green sprigs of Pluchea indica. In July 2002 nests were in all stages of the breeding cycle, but compared with Brown Boobies more nests were at earlier stages: eggs 
(10\%), small naked chicks (20\%), mediumsized downy chicks (30\%), large mostly feathered chicks $(30 \%)$, and fully feathered chicks (10\%). On 28 September 2003 at least one nest contained a partly feathered chick.

Red-footed Boobies prefer to nest in trees and shrubs if they are available, and much of the vegetation more than a few inches high was used for nesting, but a few nests were on the ground, suggesting that the population of Red-footed Boobies on Lehua may be limited by nest sites. Some of the Pluchea indica and Abutilon grandifolium shrubs used for nesting showed evidence of gnawing, probably from feral rabbits.

GREAT FRIGATEBIRD OR 'IWA (Fregata minor): On 7 July 2002 we observed a total of 326 Great Frigatebirds, most of which left the island early in the morning and returned at dusk. We observed males displaying in Pluchea shrubs on the western end of the inner crescent, but a close inspection of the site revealed no nests. Caum (1936) reported a few nesting pairs, and it is possible that this species still nests sporadically on Lehua.

GREAT BLUE HERON (Ardea herodias): A single individual was observed on the island by boat on 29 June 2000 and 8 September 2000 (D. Kuhn and P. Donaldson, pers. comm.).

Cattle egret (Bubulcus ibis): Cattle Egrets were deliberately introduced to Kaua'i, O'ahu, Moloka'i, Maui, and Hawai'i from July to August 1959 (Breese 1959), but they have not been reported previously on Lehua. We observed increasing numbers of egrets from February 2002 to June 2003, with up to 87 adults and 21 nests, and we regularly observed birds commuting between Ni'ihau and Lehua. Cattle Egrets are known to be opportunistic predators of bird eggs and nestlings (Telfair 1994) and could pose a threat to nesting seabirds. Although we did not observe any predation, boobies often acted defensively toward egrets and pecked at them. Cattle Egrets and Red-footed Boobies nested in close proximity in the limited areas of taller vegetation and may compete for nest sites.

BLACK-CROWNED NIGHT-HERON OR 'AU$\mathrm{KU}^{\prime} \mathrm{U}$ (Nycticorax nycticorax): This indigenous species is a fairly common resident on all of the main Hawaiian Islands (Pyle 2002) but has not been reported previously on Lehua. We observed a single bird in subadult plumage on several occasions in July 2004.

PEREGRINE FALCON (Falco peregrinus): This species is a rare winter visitor to the $\mathrm{Ha}$ waiian Islands (Pyle 2002) and has not been reported previously on Lehua. It recently was removed from the Federal list of endangered species but is still a species of conservation concern (U.S. Fish and Wildlife Service $2002 a$ ). We observed one individual on 20 December 2002 and 20 February 2003, and single birds have been observed on several occasions by David Kuhn.

GLAUCOUS-WINGED GULL (Larus glaucescens): This species is a rare but regular winter visitor to the Hawaiian Islands (Pyle 2002) and has not been reported previously on Lehua. We observed one bird in first-year plumage on two occasions in February 2002.

SOOTY TERN OR 'EWA'EWA (Sterna fuscata) and GRAY-BACKED TERN OR PĀKALAKALA (Sterna lunata): Large numbers of these species nest in the Northwestern Hawaiian Islands, with smaller numbers on Ka'ula and on islets off O'ahu (Harrison 1990), but neither species has been reported previously on Lehua. We observed one or two Sooty Terns flying over the island in February 2002, May 2003, and July 2004, and a single Graybacked Tern on 6 July 2002. Suitable nesting habitat for these species is present on Lehua, and their absence may be due to the presence of rats and Barn Owls. Barn Owls are known to have preyed on Sooty and Gray-backed Terns on Ka'ula (R.L.W., in Berger 1981).

B ROWN NODDY OR NOIO KŌHĀ (Anous stolidus): Caum (1936) described this species as fairly common, and R.L.W. reported approximately 500 individuals in 1967 , but in 20022005 we observed only a single individual foraging off the southern shore. We collected several Brown Noddy bones from the Barn Owl roost. The current absence of this species on Lehua may be due to predation by owls and possibly rats.

HAWAIIAN (BLACK) NODDY OR NOIO (Anous minutus melanogenys): This subspecies is endemic to the main Hawaiian Islands, including Lehua, with $A$. m. marcusi occurring 
in the Northwestern Hawaiian Islands east to Nīhoa (Gauger 1999). We observed Hawaiian Noddies on every visit, with a maximum of 365 birds in July 2002 in the large sea cave and an additional 40 birds in the small sea cave. On 1 June 2003 we observed nests in all stages of the breeding cycle, including copulating pairs, eggs, adults incubating and brooding small chicks, and 10 recently fledged juveniles. Black Noddies may have persisted on Lehua while Brown Noddies were extirpated because Black Noddies nest on ledges in the back of sea caves that are less accessible to predators. Fisher (1951), Harrison (1990), and R.L.W. (unpubl. data) reported several hundred Hawaiian Noddies, but Caum (1936) reported that the Hawaiian Noddy was rare and that it nested in caves with Brown Noddies, which is suspicious. Brown Noddies generally do not nest in caves, and Caum's observation that Hawaiian Noddies were rare may have been caused by misidentification as Brown Noddies.

BARN OwL (Tyto alba): Barn Owls were deliberately introduced to Kaua'i, Hawai'i, O'ahu, and Moloka'i from 1958 to 1963 to control rats (Berger 1981), but they have not been reported previously on Lehua. We observed Barn Owls in 2004 and 2005, and their continued presence was revealed on every visit by fresh pellets at roost sites and by fresh prey remains. A sediment deposit beneath a roost on the southern shore contained thousands of bones from Polynesian rats, feral rabbits, Bulwer's Petrels, Brown Noddies, Zebra Doves, and several other bird species. One pellet contained the entire skull of a Wedge-tailed Shearwater, demonstrating that Barn Owls can prey on relatively large species. white-RUMPED SHAMa (Copsychus malabaricus): A single female shama was observed near the summit of the islet in October 2005. This alien species is common on $\mathrm{O}^{\prime}$ ahu and Kaua' $i$ and has recently become established on Moloka'i, but it has not been recorded previously on Lehua.

\section{DISCUSSION}

Lehua Islet is an interesting and important seabird nesting site for several reasons. Geo- graphically, Lehua occupies an intermediate position in the Hawaiian Archipelago, near the juncture of the main Hawaiian Islands and the Northwestern Hawaiian Islands. Lehua supports the westernmost breeding colonies of Newell's Shearwater, Band-rumped Storm-Petrel, and Hawaiian Noddy and the easternmost colony of Black-footed Albatross. Numerically, the Brown Booby and Red-footed Booby colonies on Lehua are the largest in the Hawaiian Islands (Harrison 1990). The breeding colonies of Black-footed Albatross and Laysan Albatross, though not large, are important because these species nest in relatively few sites. The threatened Newell's Shearwater, endangered Hawaiian Petrel, and Band-rumped Storm-Petrel, a candidate for listing, appear to be declining in some areas and may be difficult to manage on the larger Hawaiian Islands (Slotterback 2002, Wood et al. 2002, Day et al. 2003). Offshore islets such as Lehua may become increasingly important in the conservation of these species because the small size of these islets makes it more feasible to eradicate predators and manage other threats.

Some noteworthy changes in the avifauna of Lehua Islet have occurred since Caum first visited in 1931. Perhaps the most interesting change is the colonization of Lehua by Blackfooted and Laysan Albatross. Most previous surveys occurred at times when albatross would not have been nesting, so it is difficult to determine when the colonies were established. The number of albatrosses nesting on Lehua is currently small, but colonies on high islands such as Lehua may become increasingly valuable because they are less likely to be affected by increases in sea level associated with climate change. Wedge-tailed Shearwaters were reported in abundance by all previous observers, but the 23,000 pairs estimated in 2002 appear to represent a substantial increase. Numbers of abundant animals are notoriously easy to underestimate, however, and it is possible that previous estimates were too low. The increase in number of Redfooted Boobies may be due to an increase in availability of nest sites in introduced Pluchea shrubs, which were not present at the time of Caum's visits, but the reason for the apparent 
increase in the Brown Booby population is unknown.

Of the 13 bird species not recorded on Lehua before 2002-2005, one was a recent colonist (Laysan Albatross), three were uncommon seabird species that are primarily nocturnal and could have been missed during previous surveys (Hawaiian Petrel, Newell's Shearwater, and Band-rumped StormPetrel), two were common seabird species that nest on nearby islands (Sooty and Graybacked Terns), two were uncommon winter visitors that visit Hawai'i seasonally in small numbers (Peregrine Falcon and Glaucouswinged Gull), one was a native waterbird that may visit Lehua sporadically (Blackcrowned Night-Heron), and four were alien species that have become more abundant and widespread since previous surveys (Cattle Egret, Rock Dove, Barn Owl, and Whiterumped Shama).

Six bird species recorded on Lehua in the past were not observed in 2002-2005. Masked Boobies were reported to nest in small numbers by Caum (1936), but none has been observed since. Brown Noddies apparently have been extirpated from Lehua, at least in part due to predation by Barn Owls. Zebra Doves, Sky Larks, Northern Cardinals, and House Sparrows are numerous on Kaua' $i$, and probably on Nitihau, and they may still visit Lehua.

Seabirds on Lehua are being preyed upon by alien species, including Polynesian rats, Barn Owls, and possibly Cattle Egrets, and populations of some seabirds may be threatened by predation. Smaller species such as Bulwer's Petrel and Band-rumped StormPetrel are especially vulnerable to predation, and they may follow the Brown Noddy into extirpation if alien predators on Lehua are not controlled. Barn Owls are known to have preyed on large numbers of seabirds on Ka'ula Islet until they were removed (R.L.W., U.S. Fish and Wildlife Service, and A. Silva, Hawai'i Division of Forestry and Wildlife, pers. comm.). Brown Noddies, Sooty Terns, Gray-backed Terns, and Bluegray Noddies (Procelsterna cerulea) nest on Ka ula (Harrison 1990), but they are conspicuously absent from Lehua. Removal of Barn
Owls and rats from Lehua might allow these and perhaps other small seabirds to recolonize the islet.

Rabbits have been present on Lehua since before Caum's visit in 1931 and have seriously impacted the vegetation on the island (Wood and LeGrande 2006). Two seabird species on Lehua nest only in taller vegetation (Red-footed Booby and Great Frigatebird), and availability of suitable nest sites may limit populations of these species on Lehua. Eradication of rabbits and recovery of vegetation would provide more nest sites for boobies and frigatebirds and help prevent erosion and burying of seabirds burrows during heavy rains.

\section{Conservation Recommendations}

The most urgent conservation need of the avifauna on Lehua is eradication of alien predators, particularly rats and Barn Owls. This is especially important to protect smaller seabirds such as Band-rumped Storm-Petrel and Bulwer's Petrel and might allow recolonization by Brown Noddy, Sooty Tern, and Gray-backed Tern. Feral rabbits should be eradicated from Lehua to allow recovery of vegetation and habitat restoration. In addition to the obvious benefits to plants, restoration of vegetation would provide nesting platforms and erosion control to protect seabird burrows. Cattle Egrets should be controlled to prevent predation on seabird chicks and possible competition for nest sites with Redfooted Boobies. A system of paths should be established to minimize the extent of anthropogenic impacts, including crushing of seabird burrows, disturbance to nesting boobies, and trampling of vegetation. Bones recovered from the sediment under the Barn Owl roost should be identified to provide information on the diversity of vertebrate species on Lehua over time and to help guide restoration efforts.

\section{ACKNOWLEDGMENTS}

We thank Holoholo Charters for generously providing transport to and from Lehua, the Hawai $i$ Division of Forestry and Wildlife 
for logistical assistance and granting landing permits, the U.S. Coast Guard for granting landing permits, Rogelio Doratt and Laura Driscoll of the U.S. Department of Agriculture for conducting rodent surveys, David Steadman and Carla Kishinami for examining skeletal specimens, and David Kuhn and Peter Donaldson for additional bird observations. Valuable comments on the manuscript were made by Maura Naughton, Sheila Conant, and Jim Jacobi.

\section{Literature Cited}

Ainley, D. G., T. C. Telfer, and M. H. Reynolds. 1997. Townsend's and Newell's Shearwater (Puffinus auricularis). No. 297 in A. Poole and F. Gill, eds. The birds of North America. The Birds of North America, Inc., Philadelphia, Pennsylvania.

Berger, A. J. 1981. Hawaiian birdlife. 2nd ed. University of Hawai'i Press, Honolulu.

Breese, P. L. 1959. Information on Cattle Egret, a bird new to Hawaii. 'Elepaio 20:33-34.

Carson, H. L., and D. A. Clague. 1995. Geology and biogeography of the Hawaiian Islands. Pages 14-29 in W. L. Wagner and V. A. Funk, eds. Hawaiian biogeography: Evolution on a hot spot archipelago. Smithsonian Institution Press, Washington, D.C.

Caum, E. L. 1936. Notes on the flora and fauna of Lehua and Kaula Islands. Occas. Pap. Bernice P. Bishop Mus. 20 (21).

Day, R. H., B. A. Cooper, and T. C. Telfer. 2003. Decline of Townsend's (Newell's) shearwaters (Puffinus auricularis newelli) on Kauai, Hawaii. Auk 120:669-679.

Dunlap, E. 1988. Laysan Albatross nesting in Guadelupe Island, Mexico. Am. Birds 42:180-181.

Fefer, S. I., D. Hu, and M. B. Naughton. 1987. Catalog of Hawaiian seabird colonies. U.S. Fish and Wildlife Service, $\mathrm{Pa}-$ cific Islands Office, Honolulu, Hawai'i.

Fisher, H. I. 1951. The avifauna of Niihau Island, Hawaiian Archipelago. Condor 52:31-42.

Gauger, V. H. 1999. Black Noddy (Anous minutus). No. 673 in A. Poole and F. Gill, eds. The birds of North America. The Birds of North America, Inc., Philadelphia, Pennsylvania.

Harrison, C. S. 1990. Seabirds of Hawaii: Natural history and conservation. Cornell University Press, Ithaca, New York.

Hasegawa, H. 1978. The Laysan Albatross breeding in the Ogasawara Islands. Pac. Seabird Group Bull. 5:16-17.

Hodges, C. S. N., and R. J. Nagata. 2001. Effects of predator control on the survival and breeding success of the endangered Hawaiian dark-rumped petrel. Stud. Avian Biol. 22:308-318.

Howell, S. N. G., and S. Webb. 1989. Additional notes from Isla Clarion, Mexico. Condor 91:1007-1008.

- 1992. Changing status of the Laysan Albatross in Mexico. Am. Birds 46:220223.

Hu, D., C. Glidden, J. S. Lippert, L. Schnell, J. S. MacIvor, and J. Meisler. 2001. Habitat use and limiting factors in a population of Hawaiian Dark-rumped Petrels on Mauna Loa, Hawai'i. Stud. Avian Biol. 22:234-242.

International Union for the Conservation of Nature. 2003. IUCN red list of threatened species. International Union for the Conservation of Nature, Gland, Switzerland.

Megyesi, J. L., and D. L. O'Daniel. 1997. Bulwer's Petrel (Bulweria bulwerii). No. 281 in A. Poole and F. Gill, eds. The birds of North America. The Birds of North America, Inc., Philadelphia, Pennsylvania.

Pitman, R. L. 1985. The marine birds of Alijos Rocks, Mexico. West. Birds 16:81-92.

- 1988. Laysan Albatross breeding in the eastern Pacific_-and a comment. Pac. Seabird Group Bull. 15:52.

Pyle, R. L. 2002. Checklist of the birds of Hawaii-2002. 'Elepaio 62:137-148.

Richardson, F. 1963. Birds of Lehua Island off Niihau, Hawaii. 'Elepaio 23:43-45.

Simons, T. R., and C. N. Hodges. 1998. Dark-rumped Petrel (Pterodroma phaeopygia). No. 345 in A. Poole and F. Gill, eds. The birds of North America. The Birds of North America, Inc., Philadelphia, Pennsylvania.

Slotterback, J. W. 2002. Band-rumped 
Storm-Petrel (Oceanodroma castro) and Tristram's Storm-Petrel (Oceanodroma tristrami). No. 673 in A. Poole and F. Gill, eds. The birds of North America. The Birds of North America, Inc., Philadelphia, Pennsylvania.

Sugimura, N., D. G. Smith, M. Ono, B. R. Liesemeyer, and C. Swenson. 2003. Effects of predator control on seabird breeding at Kaena Point, Oahu, Hawai'i. Poster presentation, Hawai' $i$ Conservation Conference, Honolulu, Hawai'i.

Telfair, R. C., II. 1994. Cattle Egret (Bubulcus ibis). No. 113 in A. Poole and F. Gill, eds. The birds of North America. The Birds of North America, Inc., Philadelphia, Pennsylvania.

U.S. Fish and Wildlife Service. 2002a. Birds of conservation concern 2002. Division of Migratory Bird Management, Arlington, Virginia.

. 2002b. Endangered and threatened wildlife and plants; review of species that are candidates or proposed for listing as endangered or threatened; annual notice of findings on recycled petitions; annual description of progress on listing actions. Fed. Regis. 67:40657-40679.

. 2005. Regional seabird conservation plan, Pacific region. U.S. Fish and Wildlife Service, Migratory Birds and Habitat Programs, Pacific Region, Portland Oregon.
Whittow, G. C. 1993a. Black-footed Albatross (Phoebastria nigipes). No. 65 in A. Poole and F. Gill, eds. The birds of North America. The Birds of North America, Inc., Philadelphia, Pennsylvania.

- 1993b. Laysan Albatross (Phoebastria immutabilis). No. 66 in A. Poole and F. Gill, eds. The birds of North America. The Birds of North America, Inc., Philadelphia, Pennsylvania.

. 1997. Wedge-tailed Shearwater (Puffinus pacificus). No. 305 in A. Poole and F. Gill, eds. The birds of North America. The Birds of North America, Inc., Philadelphia, Pennsylvania.

Wood, K. R., D. Boynton, E. VanderWerf, L. Arnold, M. LeGrande, J. W. Slotterback, and D. Kuhn. 2002. The distribution and abundance of the Band-rumped Storm-Petrel (Oceanodroma castro): A preliminary survey on Kaua'i, Hawai'i. Report to the U.S. Fish and Wildlife Service, Pacific Islands Office, Honolulu, Hawai'i. Available from U.S. Fish and Wildlife Service.

Wood, K. R., and M. LeGrande. 2006. An annotated checklist and new island records of flowering plants from Lehua Islet, $\mathrm{Ni}^{6} \mathrm{i}$ hau, Hawai'i. In N. L. Evenhuis and L. G. Eldredge, eds. Records of the Hawaii Biological Survey for 2004-2005. Bishop Mus. Occas. Pap. 86:19-29. 